\title{
Appropriate Fiscal Policy over the Business Cycle: Proper Stimulus Policies Can Work
}

\author{
Philip E. Graves
}

CESIFO WORKING PAPER NO. 3160

CAtegory 6: Fiscal Policy, Macroeconomics AND Growth

August 2010

\footnotetext{
An electronic version of the paper may be downloaded

- from the SSRN website: Www.SSRN.com

- from the RePEc website: Www.RePEc.org

- from the CESifo website: www.CESifo-group.org/wp
} 


\title{
Appropriate Fiscal Policy over the Business Cycle: Proper Stimulus Policies Can Work
}

\begin{abstract}
Fiscal policy has become quite controversial in the post-Keynesian era, the debate over the Obama stimulus package being a contentious recent example. Some pundits go so far as to take the position that macroeconomic theory has failed to meaningfully progress in terms of providing useful recommendations for policy-makers, particularly in times of recession. Others take the laissez-faire view that policy reactions to the business cycle do not help in a rational expectations world and indeed do harm by increasing uncertainty. Still others, while not necessarily viewing themselves as in any sense "Keynesian," have a nagging feeling that sometimes doing nothing must be worse than doing something...but what to do? Sensible guidance is provided here on how governments should spend taxpayer dollars and on how that spending should change under varying economic conditions. The nature of public goods, namely whether they are complements, substitutes, or neutral to private goods, is seen to be critical to such decisions.
\end{abstract}

JEL-Code: E12, E13, E32, E61, E62, E66, H11, H30, H50.

Keywords: fiscal policy, business cycles, public goods, recessions, boomtimes.

Philip E. Graves

Department of Economics

University of Colorado

USA - Boulder, CO 80309

philip.graves@colorado.edu

I would like to acknowledge the support of CESifo where I wrote this paper during a three week visit in the summer of 2010. 


\section{Introduction}

Many economists believe that the traditionally-defined Keynesian multiplier is essentially zero or perhaps in certain, relatively rare, cases perhaps slightly positive. For example, Barro (2009) makes a number of seemingly reasonable arguments indicating that the government multiplier for wartime expenditures was less than 1.0 and that the multiplier for peacetime expenditures was "statistically insignificantly different from zero." This is, of course, what one would expect from even a cursory glance at the production possibilities frontier of microeconomic principles classes, if the economy is on or reasonably near that frontier.

If such assertions are valid, however, they cast great doubt on the impact of the Obama stimulus package on the economy. Indeed, if the stimulus package is comprised of many projects that would fail a properly-conducted benefit-cost test, economic welfare could take a big hit-we do not want to take high value inputs, or at least potentially high value inputs, to create low value outputs. Regardless of any stimulus to the economy, such projects are simply too wasteful.

Additionally, one might expect that greatly increased government spending, particularly when debt financed, is likely to cause rational individuals to behave in ways that would offset any stimulus that might have otherwise been forthcoming. One would anticipate, and we are starting to observe, that rational individuals would increase savings rates in anticipation of higher future tax burdens associated with the financing of large deficits. This would be true even holding status quo expectations about future interest rates. If Treasury bond-holders become more nervous about rising debt/GDP ratios and cause interest rates to rise, this effect would be greatly exacerbated, further hindering any stimulus-related recovery. 
What sort of stimulus, if any, is likely to work? One can immediately reject government provision of useful ordinary private goods-one would expect private demands to fall in proportion to government provision, leaving no stimulus. Additionally, the private sector is likely to be more efficient at providing private goods in any event. We are left, then, with public goods...goods that would not be produced by the private sector.

But all public goods are not created equal. Two types of public goods can be rejected for a stimulus package on efficiency arguments akin to those for private goods. We would not want to produce entirely "useless" public goods (e.g. pyramids, bridges to nowhere), although they might provide some stimulus in a sufficiently high unemployment economy. Such projects would not pass any reasonable benefit-cost test and would waste society's scarce resources.

Additionally, it is unlikely that we would want to provide very much in the way of public goods that have powerful existing special interest groups (e.g. national defense, with Eisenhower first warning of the dangers of the military-industrial complex), because such goods are likely to already be well provided. Again accurate benefit-cost analyses of such goods would be likely to reveal marginal benefits near or below marginal costs.

However, in Section II it is shown that provision of certain types of public goods is likely to result in peacetime fiscal multipliers substantially greater than zero, and potentially well in excess of 1.0. When public goods are neither substitutes nor complements with private goods it is seen in this section that their provision affects the labor supply decisions for two, mutually reinforcing, reasons. Section III examines cases in which public goods are either substitutes for private goods or complements with private goods. It is seen there that which policies are appropriate to proceed with will depend on the state of the economy. Section IV summarizes the implications for appropriate fiscal policy over the business cycle. 


\section{Public Goods and the Labor Supply Decision}

As noted by Flores and Graves (2008), conventional benefit-cost analysis of public goods provision aggregates individual willingness to pay while treating income as exogenous, ignoring the fact that we generate income to allow us to purchase utility-generating goods. They show that policies increasing the levels of public goods provided will generally result in an increase in labor supply, and that failing to endogenize the labor/leisure decision generally results in the under-provision of public goods. ${ }^{1}$ For present macroeconomic concerns, what this means is that provision of such goods — even when the initial labor supply is optimal—will result in a supplyside stimulus to the economy. ${ }^{2}$

Might the previous argument be of second-order significance? If we were anywhere near the optimal levels of public goods provision, it is possible that any labor supply effects might be negligible. However, since costly benefit-cost analyses are conducted only infrequently, and with the true marginal benefits increasing over time for normal public goods, it is unlikely that we are near the social optimum for public goods lacking strong special interest support. ${ }^{3}$

There is a strong additional argument for why it is likely that public goods are generally undervalued by conventional benefit-cost methods, and that is that the initial labor supply would be unlikely to, in fact, be anywhere near optimal. As discussed in detail in Graves (2009), initial labor supplies are likely to be far from optimal, since individuals would not be expected to generate income for goods that cannot be individually increased, such as-but not limited tocertain "pure" public goods.

\footnotetext{
${ }^{1}$ They also show that for decrements to the public good, rare in practice, a benefit-cost analysis would over-value the public good.

${ }^{2}$ Flores and Graves' argument is weakened if public goods are strong complements with leisure, but this would be unlikely in general cases. For certain quasi-public goods, such as recreation areas, some complementarity might be expected, however. I return to fiscal policy implications stemming from whether public goods are complements or substitutes for private goods in Section III.

${ }^{3}$ Moreover, for many types of public goods, notably environmental quality, the methods in use by economists are biased against acceptance of a policy. See Graves 2010 for an extensive list of supporting arguments.
} 
The reasoning is straight-forward. We work to obtain the goods we want to consume. If we are unable to acquire additional amounts of some class of goods by work effort, one of two things will happen. In the absence of good private good substitutes for the public good, work effort will not be undertaken because leisure is valuable to everyone.

Illustrating, consider an ardent environmentalist, who really cares about saving species, increasing wilderness areas, lowering $\mathrm{CO}_{2}$ emissions, and the like but has limited desires for ordinary goods. If rational, she will realize that she is too small to make a difference in the collective provision decision; moreover the price she would have to pay to provide those types of goods herself is effectively infinite. She will rationally choose to only generate the income necessary to pay for her limited desires for private goods and for whatever amounts of the public good that happen to be provided. To the economist, she is indistinguishable from a "lazy person" who has no strong desires for either private or public goods-and the more that she cares for public goods the less income she will generate, in extreme cases "dropping out" like a sixties hippie. Cost-benefit analyses of the public goods that environmentalists care about will be conducted at the wrong income level and all of ungenerated income would have been spent on the public good, ignoring general equilibrium effects. ${ }^{4}$

We are not all ardent environmentalists, of course, but everyone cares somewhat about various public goods - any goods actually that cannot be individually incremented — and to the extent that we care about such goods we have incentives to under-generate income because leisure is valuable for everyone. ${ }^{5}$

\footnotetext{
${ }^{4}$ Were the public good optimally incremented, environmentalists' marginal values would begin falling as would how much leisure they would give up for still higher levels of the public good.

${ }^{5}$ Given the large variation in tastes, human capital, and non-labor income, it is likely that even when public goods are substantially underprovided, the provision level will be non-optimally large from the perspective of certain individuals. This would reduce the quantitative importance of the text arguments somewhat.
} 
Is there any evidence to suggesting much real-world importance for the argument that certain public goods are under-provided? Yes, there appears to be a gap between willingness-topay and willingness-to-accept that is particularly large for public goods. ${ }^{6}$ The very large gap between these measures suggests that the arguments made here could well have merit.

If people are asked, for example, what a one percent improvement in air quality is worth to them, they will respond with very small values. But when asked how much they would have to be compensated to have air quality become worse by one percent, the numbers are much greater, often orders of magnitude larger. Many explanations for this phenomenon have been advanced, with Daniel Kahneman receiving the Nobel Prize in part for characterizing the WTAWTP gap as due to an "endowment effect.",

The arguments here, however, are based on traditional utility theory with "input market free riding" that is a variant of the well-known "output market free riding" behavior. Hence the present arguments might appeal to those who want a less ad hoc reason for WTP values that are so low relative to WTA values. Willingness-to-pay is so low, in the present view, because it is being mis-measured, with the ungenerated income of those desiring goods they cannot individually acquire not being observed as demands for public goods provision by economists conducting cost-benefit analyses.

The arguments of this section indicate that, under normal macroeconomic conditions, government expenditure on public goods lacking special interest backing are very likely to have positive supply-side multipliers that have not been discussed at all in the economics literature.

\footnotetext{
${ }^{6}$ See Horowitz and McConnell (2002) for evidence from a survey of forty-five experimental studies that the WTAWTP gap is particularly large for public goods.

${ }^{7}$ Kahneman et al. (1990) and Twersky and Kahneman (1991) proposed the psychological "endowment effect," Boyce et al. (1992) argue that a sense of moral responsibility might account for the phenomenon, Hanemann (1991) examines implications of poor substitution possibilities, and Walton et al.(2002) argue that value uncertainty might result in gaps of the type observed. It is perhaps likely that each explanation is of relevance in particular settings.
} 
That is, in terms of a simple production possibility frontier between ordinary goods and public goods, increasing the levels of the public good will result in reductions in leisure that shift the entire curve outward. ${ }^{8}$

The public good expenditure multiplier will, then, not only be greater than zero, but indeed will be unity if public goods are independent of private goods. As shown in Graves (2009), for the simple case of the Cobb-Douglas utility function in which variable coefficients are also expenditure shares, income generated will increase dollar-for-dollar with increased public goods provision, with welfare gains up to the optimal provision point.

\section{Policy Implications When Public and Private Goods Are Complements or Substitutes}

What are the implications of the arguments here for the multipliers associated with public policy in a world of business cycles? Contrary to the discussion of the previous section, some of the under-provided public goods will be complements with private goods while other such goods will be substitutes for private goods. The implications for appropriate public policy in these cases are startlingly simple.

During times of recession, the government (at all levels) should be producing public goods that are complementary with private goods. The increases in these public goods will result in more income being generated, but now a still larger income will be generated. In part, individuals demanding public goods will be generating income to pay for what they were wanting all along as discussed above. But, it is also the case that as the public good is increased, there will now be an increase in the demand for complementary private goods.

\footnotetext{
${ }^{8}$ The outward shift will not be homothetic but will favor the public good if public goods are neither substitutes nor complements with private goods. This follows from the fact that it is only the inability to individually increment the public good that is the source of the initial under-supply of labor, an under-supply that is reduced by increased public good provision. With public goods on the horizontal axis, the shift would be parallel to the right under independence, with the same amount of private goods being selected before and after increases in the public good.
} 
Examples are many, but consider a few important cases. Roadways are clearly complementary with automobiles-building new roads and improving existing roads will stimulate the demand for automobiles. One would expect that an environmental cleanup of a polluted river would stimulate demand for boats. Cleaning up a park might result in greater sales of picnic baskets and associated goods. In such cases, the desire to generate income is greater than if the public good were unrelated to private goods.

For public goods that are complementary with private goods, multipliers would be expected to exceed 1.0, ${ }^{9}$ and this expectation has nothing to do with traditional Keynesian respending arguments. Any traditional demand-side stimulus, for those who believe in this possibility, would merely work to increase the magnitude of the multipliers discussed here.

In boomtimes, the government, again at all levels, should attempt to focus more on the production of public goods that are substitutes for private goods, the notion being to reduce the aggregate demand pressures that would otherwise be present. There are again many examples of public goods that are substitutes for private goods. Increasing levels of public mass transit would work to reduce the demand for automobiles. Providing greater public safety might lead to reduced expenditures on door locks, window bars, and handguns. These sorts of expenditures will be less likely to fuel inflation when unemployment levels approach the full employment natural rate.

In the quite unlikely case that the public good under consideration has perfect private good substitutes, the multiplier would be zero or close to that. Households would generate the same income level and merely switch from buying private goods to paying their share of the public good.

\footnotetext{
${ }^{9}$ The text assertion that public good multipliers could exceed unity when under-supplied public goods are complementary with private goods is a result that Barro, although in a Keynesian context, claims "would make Charles Ponzi proud."
} 


\section{Summary and Conclusions}

It should first be emphasized that the arguments here do not constitute support for projects that could not pass a properly-conducted benefit-cost test. However, the arguments here do indicate that benefit-cost analyses of many classes of public goods are almost certainly being conducted at the wrong income levels at present, with all the ungenerated income representing unobserved demands for the public goods.

Moreover, public goods are not all equally likely to suffer from insufficient provision levels. Any public good for which strong special interest lobbying exists (e.g. national defense) is less likely to be under-provided for reasons long discussed in the public choice literature. Moreover, such goods have usually been produced for many decades or even centuries.

But other public goods only begin being supplied, directly or indirectly via regulation, only after a long period of political pressure (e.g. the environmental movement gradually leading up to the creation of the EPA in 1970 in the U.S., with important air and water legislation coming a bit later). Initial provision levels for such goods are likely to conservative, with provision at first well below what a proper-conducted benefit-cost analysis could justify. This pattern, if typical, guarantees that the problem emphasized here of free riding in input markets with consequent unobserved demands will plague subsequent benefit-cost analyses for such goods.

Summarizing, to the extent that government spending is devoted to public goods that do not have powerful special interest support, particularly public goods that appear to have high disparities between willingness-to-pay and willingness-to-accept, American households will experience a welfare gain if that spending is increased. This is true regardless of whether the public good is independent, complementary, or a substitute for private goods. 
If, however, a public good is independent of private goods one would expect a supplyside multiplier of about one, a dollar for dollar increase in income with increased public good expenditure. There will be no crowding out of private goods, in this case.

Multipliers will be larger than one if public goods are produced that are complementary with private goods, and the greater the degree of complementarity the larger will be the multiplier. As a consequence, public goods that are complementary with private goods (e.g. roads and automobiles) should receive greater emphasis in public policy during recessionary periods, since both the public good provision and the concomitant greater demands for private goods will serve to stimulate the economy.

Multipliers will be smaller than one if public goods are produced that are substitutes for private goods, approaching zero in the extreme case of perfect substitutes. Public goods that are substitutes for private goods (e.g. mass transit and automobiles) should receive greater emphasis in public policy during boomtimes to reduce the pressure on aggregate demand — what might look like "crowding out" in this case merely stems from the lower value that private good substitutes have when the public good is increased.

In more normal years of near-full employment, optimal policy can become much more flexible. Certainly public goods that are independent of private goods and can pass a properlyconducted benefit-cost test should be pursued-income will grow with neither contractionary nor expansionary consequences. But it is also the case in such years that a mix of public goods, some complements with private goods and some substitutes for private goods, could be pursued with a net impact, at least in principle, similar to that of providing public goods which are independent of private goods. 


\section{References}

Barro, R.J. (2009). Demand side voodoo economics, The Economists' Voice: Vol. 6 : Iss. 2, Article 5. See: http://www.bepress.com/ev/vol6/iss2/art5

Boyce, R.R., T.C. Brown, G.H. McClelland, G.L. Peterson and W.D. Schulze (1992). An experimental examination of intrinsic values as a source of the WTA-WTP disparity. American Economic Review 82(6), 1366-1373.

Flores, N.E. and P.E. Graves (2008). Optimal public goods provision: Implications of endogenizing the labor/leisure decision, Land Economics, 84 (4), 701-707.

See: http://papers.ssrn.com/sol3/papers.cfm?abstract_id=1477162

Graves, P. E. (2009). A note on the valuation of collective goods: Overlooked input market free riding for non-individually incrementable goods," The B.E. Journal of Economic Analysis \& Policy: Vol. 9: Iss. 1 Topics, Article 5.

See: http://www.bepress.com/bejeap/vol9/iss1/art5

Graves, P. E. (2010). Benefit-cost analysis of environmental projects: A plethora of systematic biases. Manuscript. See: http://papers.ssrn.com/sol3/papers.cfm?abstract_id=1649309

Hanemann, W. M., 1991. Willingness to pay and willingness to accept: How much can they differ? American Economic Review 81(3), 635-647.

Horowitz, J.K. and K.E. McConnell (2002). A review of WTA/WTP studies. Journal of Environmental Economics and Management. 44, 426-447.

Kahneman, D., J. L. Knetsch and R. H. Thaler, (1990). Experimental tests of the endowment effect and the Coase Theorem. Journal of Political Economy 93, 1325-1348.

Tversky, A. and D. Kahneman (1991). Loss aversion in riskless choice: A reference-dependent model. Quarterly Journal of Economics 104(4), 1039-1062. 
Walton, S.M., P.E. Graves, P.R. Mueser, and J.K. Dow (2002). The bias against new innovations in health care: Value uncertainty and willingness-to-pay. Value in Health, 5 (2), 67-70. 


\section{CESifo Working Paper Series}

for full list see www.cesifo-group.org/wp

(address: Poschingerstr. 5, 81679 Munich, Germany, office@cesifo.de)

3097 Assar Lindbeck and Mats Persson, A Continuous Theory of Income Insurance, June 2010

3098 Thomas Moutos and Christos Tsitsikas, Whither Public Interest: The Case of Greece's Public Finance, June 2010

3099 Thomas Eichner and Thorsten Upmann, Labor Markets and Capital Tax Competition, June 2010

3100 Massimo Bordignon and Santino Piazza, Who do you Blame in Local Finance? An Analysis of Municipal Financing in Italy, June 2010

3101 Kyriakos C. Neanidis, Financial Dollarization and European Union Membership, June 2010

3102 Maela Giofré, Investor Protection and Foreign Stakeholders, June 2010

3103 Andrea F. Presbitero and Alberto Zazzaro, Competition and Relationship Lending: Friends or Foes?, June 2010

3104 Dan Anderberg and Yu Zhu, The Effect of Education on Martial Status and Partner Characteristics: Evidence from the UK, June 2010

3105 Hendrik Jürges, Eberhard Kruk and Steffen Reinhold, The Effect of Compulsory Schooling on Health - Evidence from Biomarkers, June 2010

3106 Alessandro Gambini and Alberto Zazzaro, Long-Lasting Bank Relationships and Growth of Firms, June 2010

3107 Jenny E. Ligthart and Gerard C. van der Meijden, Coordinated Tax-Tariff Reforms, Informality, and Welfare Distribution, June 2010

3108 Vilen Lipatov and Alfons Weichenrieder, Optimal Income Taxation with Tax Competition, June 2010

3109 Malte Mosel, Competition, Imitation, and R\&D Productivity in a Growth Model with Sector-Specific Patent Protection, June 2010

3110 Balázs Égert, Catching-up and Inflation in Europe: Balassa-Samuelson, Engel's Law and other Culprits, June 2010

3111 Johannes Metzler and Ludger Woessmann, The Impact of Teacher Subject Knowledge on Student Achievement: Evidence from Within-Teacher Within-Student Variation, June 2010 
3112 Leif Danziger, Uniform and Nonuniform Staggering of Wage Contracts, July 2010

3113 Wolfgang Buchholz and Wolfgang Peters, Equity as a Prerequisite for Stable Cooperation in a Public-Good Economy - The Core Revisited, July 2010

3114 Panu Poutvaara and Olli Ropponen, School Shootings and Student Performance, July 2010

3115 John Beirne, Guglielmo Maria Caporale and Nicola Spagnolo, Liquidity Risk, Credit Risk and the Overnight Interest Rate Spread: A Stochastic Volatility Modelling Approach, July 2010

3116 M. Hashem Pesaran, Predictability of Asset Returns and the Efficient Market Hypothesis, July 2010

3117 Dorothee Crayen, Christa Hainz and Christiane Ströh de Martínez, Remittances, Banking Status and the Usage of Insurance Schemes, July 2010

3118 Eric O'N. Fisher, Heckscher-Ohlin Theory when Countries have Different Technologies, July 2010

3119 Huw Dixon and Hervé Le Bihan, Generalized Taylor and Generalized Calvo Price and Wage-Setting: Micro Evidence with Macro Implications, July 2010

3120 Laszlo Goerke and Markus Pannenberg, 'Take it or Go to Court' - The Impact of Sec. 1a of the German Protection against Dismissal Act on Severance Payments -, July 2010

3121 Robert S. Chirinko and Daniel J. Wilson, Can Lower Tax Rates be Bought? Business Rent-Seeking and Tax Competition among U.S. States, July 2010

3122 Douglas Gollin and Christian Zimmermann, Global Climate Change and the Resurgence of Tropical Disease: An Economic Approach, July 2010

3123 Francesco Daveri and Maria Laura Parisi, Experience, Innovation and Productivity Empirical Evidence from Italy's Slowdown, July 2010

3124 Carlo V. Fiorio and Massimo Florio, A Fair Price for Energy? Ownership versus Market Opening in the EU15, July 2010

3125 Frederick van der Ploeg, Natural Resources: Curse or Blessing?, July 2010

3126 Kaisa Kotakorpi and Panu Poutvaara, Pay for Politicians and Candidate Selection: An Empirical Analysis, July 2010

3127 Jun-ichi Itaya, Makoto Okamura and Chikara Yamaguchi, Partial Tax Coordination in a Repeated Game Setting, July 2010

3128 Volker Meier and Helmut Rainer, On the Optimality of Joint Taxation for NonCooperative Couples, July 2010 
3129 Ryan Oprea, Keith Henwood and Daniel Friedman, Separating the Hawks from the Doves: Evidence from Continuous Time Laboratory Games, July 2010

3130 Mari Rege and Ingeborg F. Solli, The Impact of Paternity Leave on Long-term Father Involvement, July 2010

3131 Olaf Posch, Risk Premia in General Equilibrium, July 2010

3132 John Komlos and Marek Brabec, The Trend of BMI Values by Centiles of US Adults, Birth Cohorts 1882-1986, July 2010

3133 Emin Karagözoğlu and Arno Riedl, Information, Uncertainty, and Subjective Entitlements in Bargaining, July 2010

3134 John Boyd, Gianni De Nicolò and Elena Loukoianova, Banking Crises and Crisis Dating: Theory and Evidence, July 2010

3135 Michael R. Baye, Dan Kovenock and Casper G. de Vries, The Herodotus Paradox, July 2010

3136 Martin Kolmar and Hendrik Rommeswinkel, Group Contests with Complementarities in Efforts, July 2010

3137 Carolina Manzano and Xavier Vives, Public and Private Learning from Prices, Strategic Substitutability and Complementarity, and Equilibrium Multiplicity, July 2010

3138 Axel Löffler, Gunther Schnabl and Franziska Schobert, Inflation Targeting by Debtor Central Banks in Emerging Market Economies, July 2010

$3139 \mathrm{Yu}-\mathrm{Fu}$ Chen and Michael Funke, Global Warming and Extreme Events: Rethinking the Timing and Intensity of Environmental Policy, July 2010

3140 Lawrence M. Kahn, Labor Market Policy: A Comparative View on the Costs and Benefits of Labor Market Flexibility, July 2010

3141 Ben J. Heijdra, Jochen O. Mierau and Laurie S.M. Reijnders, The Tragedy of Annuitization, July 2010

3142 Erkki Koskela, Outsourcing Cost and Tax Progression under Nash Wage Bargaining with Flexible Outsourcing, July 2010

3143 Daniel Osberghaus and Christiane Reif, Total Costs and Budgetary Effects of Adaptation to Climate Change: An Assessment for the European Union, August 2010

3144 Philip E. Graves, Benefit-Cost Analysis of Environmental Projects: A Plethora of Systematic Biases, August 2010

3145 Sabrina Di Addario and Daniela Vuri, Entrepreneurship and Market Size. The Case of Young College Graduates in Italy, August 2010 
3146 Shoshana Amyra Grossbard and Alfredo Marvăo Pereira, Will Women Save more than Men? A Theoretical Model of Savings and Marriage, August 2010

3147 Jarko Fidrmuc, Time-Varying Exchange Rate Basket in China from 2005 to 2009, August 2010

3148 Ilja Neustadt and Peter Zweifel, Is the Welfare State Sustainable? Experimental Evidence on Citizens' Preferences for Redistribution, August 2010

3149 Marcus Dittrich and Andreas Knabe, Wage and Employment Effects of Non-Binding Minimum Wages, August 2010

3150 Shutao Cao, Enchuan Shao and Pedro Silos, Fixed-Term and Permanent Employment Contracts: Theory and Evidence, August 2010

3151 Ludger Woessmann, Cross-Country Evidence on Teacher Performance Pay, August 2010

3152 Lorenzo C. G. Pozzi, Casper G. de Vries and Jorn Zenhorst, World Equity Premium Based Risk Aversion Estimates, August 2010

3153 Volker Grossmann, Thomas M. Steger and Timo Trimborn, Dynamically Optimal R\&D Subsidization, August 2010

3154 Alexander Haupt, Tim Krieger and Thomas Lange, A Note on Brain Gain and Brain Drain: Permanent Migration and Education Policy, August 2010

3155 António Afonso and Christophe Rault, Long-run Determinants of Sovereign Yields, August 2010

3156 Franziska Tausch, Jan Potters and Arno Riedl, Preferences for Redistribution and Pensions. What can we Learn from Experiments?, August 2010

3157 Martin Kolmar and Andreas Wagener, Inefficient Group Organization as Optimal Adaption to Dominant Environments, August 2010

3158 Kai Carstensen, Klaus Wohlrabe and Christina Ziegler, Predictive Ability of Business Cycle Indicators under Test: A Case Study for the Euro Area Industrial Production, August 2010

3159 Horst Rottmann and Timo Wollmershäuser, A Micro Data Approach to the Identification of Credit Crunches, August 2010

3160 Philip E. Graves, Appropriate Fiscal Policy over the Business Cycle: Proper Stimulus Policies Can Work, August 2010 